\title{
Precursor Plasma Cell to Lymphocyte Ratio Measurement
}

National Cancer Institute

\section{Source}

National Cancer Institute. Precursor Plasma Cell to Lymphocyte Ratio Measurement. NCI

Thesaurus. Code C74650.

The determination of the ratio of precursor plasma cells compared to all lymphocytes

present in a sample. The measurement may be expressed as a ratio or percentage. 